\title{
TRADISI BERPIKIR DALAM USUL FIKIH \\ (Memetakan Porsi, Posisi dan Proporsi Akal Sebagai Nalar Berpikir dalam Hukum Islam)
}

\author{
Syamsul Wathani \\ UIN Sunan Kalijaga Yogyakarta \\ Jalan Marsda Adisucipto Yogyakarta \\ Email:wathoni89@gmail.com
}

\begin{abstract}
Abstrak
Artikel ini membahas akal sebagai sebuah nalar berfikir dalam tradisi usul fikih. Pendekatan yang digunakan adalah pendekatan kategoris-kritis, untuk melihat dan memetakan porsi, posisi dan proporsi akal sebagai alat atau metode dalam melahirkan hukum Islam. Artikel ini diharapkan bisa memetakan dan menempatkan akal secara bijak dalam peran dan aktivitasnya sebagai perangkat dalam mengeluarkan hukum Islam. Meletakkan akal sebagai metode berfikir hukum Islam di tempatnya secara proporsional. Memberikan pandangan mengenai penggunakan akal sebagai sebuah concern dalam tradisi kajian usul fikih. Serta menghilangkan justifikasi negatif mengenai penggunaan akal dalam melahirkan hukum agama.
\end{abstract}

Kata kunci: akal, tradisi berpikir, usul fikih, pendekatan kategoris, hukum Islam

\begin{abstract}
This article discusses reasoning as a thinking mode within usul fiqh tradition. The perspective used is a categorical-criticism approach to reveal and map the portion, position, and proportion of reasoning as the instruments or mode to formulate Islamic Law. This article is expected to categorize and place reasoning wisely within its roles and activity as the collection of instruments to formulate Islamic Law. This article places reasoning as the method of thinking on Islamic Law proportionally. It contributes in revealing its opinion about the use of reasoning as the concern within $u s u l$ figh, to dismiss the negative justification about the use of reasoning to formulate religious laws.
\end{abstract}

Keywords: reason, thinking tradition, usul fiqh, categorical approach, Islamic law

\section{A. Pendahuluan}

Peran akal dalam melahirkan hukum Islam, undang-undang, fatwa atau produk hukum Islam lainnya sangatlah signifikan. Sebagai sebuah anugerah yang membedakan manusia dengan makhluk lain, akal menjadi alat sekaligus mesin yang menggerakkan tradisi berfikir dalam kelimuan hukum Islam. Beberapa ulama bahkan memandang akal sebagai "rasul" dalam diri manusia, sedangkan
Muhammad saw adalah rasul di luar diri manusia. Ia memiliki peran yang begitu besar sebagai penalaran independen (independent reasoning) dalam menemukan kebenaran. '

Akal merupakan salah satu persoalan yang menjadi tema sentral dalam tradisi pemikiran agama Islam, terutama peran pentingnya dalam melahirkan hukum Islam. Dalam tradisi Islam, cara berfikir mengenai hukum 
bermuara pada ușul al-fiqh. ${ }^{2}$ Sebagai sebuah disiplin ilmu yang membahas berbagai hal terkait metode pembacaan, pendekatan penemuan hukum, serta peran akal dalam menemukan atau menciptakan sebuah hukum. ${ }^{3}$

Melihat kitab fikih yang berjilidjilid disandingkan dengan wahyu yang mendasarinya hanya berjumlah ratusan saja, tentu menjadi bukti akan peran penting akal dalam melahirkan fikih (hukum) tersebut. ${ }^{4}$ Bahkan dalam catatan sejarah, terdapat aliran hukum Islam yang menggunakan akal sebagai sumber utama pembentukan hukum. ${ }^{5}$ Akal yang rnemiliki sifat selalu mencari, menghayati, ingin mengetahui dan memiliki sense of crisis, tentu akan sangat efektif dalam mengoperasikan dialog lintas tradisi, lintas budaya, bahkan lintas historisitas dalam membahas tema spesifik studi Islam, tak terkecuali didalamnya studi hukum Islam. $^{6}$

Dalam tradisi usul fikih, peran akal secara signifikan terlihat dalam aktivitas ijtihad (intellectual exercise). ${ }^{7}$ Pola penggunaan akal telah berhasil melahirkan beragam metode ijtihad. ${ }^{8}$ Sehingga, terbaginya sumber hukum Islam (mașädir al-ahkäm) menjadi naqli dan 'aqli $i^{9}$ telah menempatkan posisi akal di dua tempat yang strategis. Pertama, ia sebagai "jembatan jalan" atau "penentu jalan" dalam melahirkan hukum Islam, ${ }^{10}$ dan kedua, akal berperan sebagai alat (mesin) dalam mengkonstruksi teori-teori ușuliyyah."

Artikel ini akan membahas akal sebagai sebuah basis penalaran dalam tradisi usul fikih. Metode atau pendekatan yang digunakan adalah kategoris-kritis, ${ }^{12}$ dengan titik fokus pada analisis mengenai porsi, posisi dan proporsi akal dalam tradisi usul fikih. Fokus ini pada akhirnya akan memberikan identifikasi, pandangan dan kesimpulan yang tepat mengenai jenis, kedudukan, peran dan fungsi akal dalam tradisi usul fikih tersebut.
Dengan analisis kategoris, artikel ini akan melihat konstruksi, porsi, posisi dan proporsi akal sebagai episteme penalaran dalam tradisi usul fikih. Sedangkan, dengan analisis kritis, artikel ini mempertanyakan tentang bagaimana akal sebagai sebuah episteme berfikir dalam memahami dan mengeluarkan hukum dari sumbernya (nașs).

Dengan fokus ini, artikel ini diharapkan dapat memberikan kontribusi pada tiga haluan besar. Pertama, memberikan penjelasan mengenai akal secara baik, serta menghilangkan justifikasi negatif mengenai penggunaannya dalam melahirkan hukum agama. Kedua, meletakkan akal sebagai metode berfikir hukum Islam di tempatnya secara proporsional. Ketiga, melihat secara bijak akal sebagai pola pikir, pendapat manusia, dan bagaimana ia berperan dalam tradisi penalaran hukum Islam. Selain itu, artikel ini diharapkan pula dapat memperkuat argumen mengenai pentingnya akal sebagai sebuah concern dalam tradisi kajian usul fikih.

\section{B. Akal: Definisi dan Ruang Lingkup}

1. Akal dalam Bingkai Kajian Semantis Kata "akal" yang sudah dipopulerkan dan dipakai secara resmi dalam bahasa Indonesia ${ }^{13}$ berasal dari bahasa Arab, yakni al-'aql (العثل), dari pembentukan kata; 'aqala - ya'qilu aqlan (عقل يعقل عثل)), yang memiliki makna

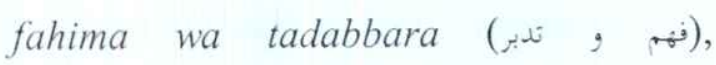
faham/memahami dan menghayati/merenungkan dengan dalam. ${ }^{14}$

Ibn Manzūr dalam Lisān alArab-nya menjelaskan, bahwa kata al'aql bermakna dasar al-hijr (الهح), yaitu menahan dan mengekang. Bentuk fä'ilnya al-äqil (العاقل) berarti orang yang menahan diri dan mengekang hawa nafsu. Derivasi kata ini kemudian melahirkan konsep, bahwa seseorang dikatakan berakal jika ia mampu menahan dirinya 
untuk memperturuti hawa nafsunya. Senada dengan Ibn Manzūr, Ibrāhim Musțafá dalam Mu'jam al-Wasit nya juga memaknai kata al-'aql dengan makna dasar kebijaksanaan (النهى), lawan kata dari lemah pikiran (المست). Beberapa ulama' lain juga menambahkan, bahwa kata $a l$ - $a q l$ bisa dimaknai pula dengan hati (القلب.).

Makna semantis yang sama juga dijumpai di kamus-kamus bahasa Arab lain, dengan makna dasar kata 'aqala, mengikat dan menahan. Dalam tinjauan sosiolinguistik, menurut Ibrāhim Mustafá, makna dasar dari al-'aql menahan dan mengikat- ini tidak terlepas dari realitas penuturnya. Karena itu, istilah tali pengikat serban yang dipakai di Arab disebut dengan 'iqal (عقل), ${ }^{16}$ dan menahan orang di dalam penjara disebut i'taqala (إعتزل), tempat tahanan disebut $m u$ 'taqal (معتى).

Dalam konteks yang lebih spesifik, bahasa Indonesia, kata "akal" dimaknai dengan dua sense penggunaan. Pertama, penggunaan akal secara umum yang dimaknai dengan daya pikir, pikiran, ingatan. Akal juga dimaknai dengan daya upaya, ikhtiar, jalan atau cara untuk melakukan sesuatu. Sehingga konsep "berakal" yang terbangun dalam konteks Indonesia dinisbatkan kepada orang yang pandai, tidak mudah kalah dalam debat. Kedua, penggunaan akal dalam kategori majaz, akal dimaknai dengan tipu daya, muslihat, kecerdikan, kelicikan, dan sebagainya. Konteks pemaknaan ini lahir dikarenakan akal sering digunakan dalam mengatur siasat (siasat buruk). ${ }^{18}$

2. Akal dalam Tinjauan al-Qur'an dan Tafsir

Materi 'aql dalam al-Qur'an memiliki banyak bentuk (variant). Diantaranya berbentuk fi'il mudari' seperti kata ta'qilün (تعقلون) atau ya'qilūn (يعلون). Terdapat juga bentuk kata 'aql dalam kata kerja, seperti kata aqaluh
(عنلود), na'qilu (نعل), dan ya'qiluhā (يعله). Lafadz 'aql dalam varisasi bentuk kata ini secara umum mengandung makna semantis yang sama, yakni paham atau memahami dan mengerti. ${ }^{9}$ Namun, dalam beberapa ayat al-Qur'an dijelaskan bahwa aktivitas pemahaman, dan pemikiran tidak hanya dilakukan melalui akal yang berpusat di kepala semata, namun juga dilakukan oleh hati (al-qalb) yang berpusat di dada. ${ }^{20}$

Konsep al-Qur'an mengenai pemahaman memang sangt luas. Jika ditinjau dari segi kajian kemiripan kata (mutarädifah) saja, ada beberapa terminologi yang digunakan al-Qur'an untuk mengambarkan aktivitas berfikir atau memahami, yakni: ${ }^{21}$ nazara (نظر), berarti melihat secara abstrak dalam arti berfikir dan merenungkan ( Q.S. Qāff: 67). Tadabbara (تدبر), berarti merenungkan (Q.S. Shād: 29), tafakkara (تفكر), berarti berfikir (Q.S. an-Nahl: 68-69), faqiha (نق), berarti mengerti/faham (Q.S. alIsra': 44), tazakkara (نذكر), berarti mengingat, memperoleh peringatan, mendapat pelajaran, memperhatikan, dan mempelajari, dan fahima (فه), yang berarti memahami (Q.S: al-Anbiya': 7879).

Lebih lanjut, al-Qur'an bahkan memberikan penghargaan dengan penyebutan tertentu kepada orang Muslim yang mau menggunakan akalnya untuk berfikir, seperti istilah: ulul-albab (أولو الألباب) orang yang berfikir, ${ }^{22}$ ulul-'ilm orang yang berilmu, ulul -abșâr (أولو الأبصار) orang yang mempunyai pandangan dan ulün-nuhā (أولأ (أنهى) orang yang bijaksana. ${ }^{23}$

Ungkapan dan ekspresi yang diberikan oleh al-Qur'an di atas mengandung anjuran, dorongan dan motivasi, bahkan perintah agar manusia banyak berpikir dan mempergunakan akalnya. Termasuk mempergunakan akal sebagai salah satu sumber ajaran Islam. ${ }^{24}$ 
Bahkan, dalam terminologi Qur'ani di atas, dengan jelas dan tegas al-Qur'an memberikan penghargaan kepada kaum Muslim yang memanfaatkan akal nya sebagai penalaran yang independen (independent reasoning) dalam melakukan 'pemahaman, meskipun dengan tidak memutlakkan kebenarannya, ${ }^{25}$ karena di samping akal, ada wahyu yang perlu juga diperhatikan.

\section{Akal Sebagai Perangkat Metodologis dalam Usul Fikih: Memetakan Porsi, Posisi, dan Proporsi Penggunaan Akal}

Usul fikih merupakan bagian dari peradaban Islam (slagäfah alIslamiyyah), tepatnya ia sebagai sentra peradaban pemikiran Islam. ${ }^{26} \mathrm{Di}$ dalam usul fikih beroperasi segala aktivitas yang memuat kaidah-kaidah berpikir ${ }^{27}$ dan bangunan keilmuan yang memaknai relasi positif antara akal dengan ilmu. Ali Harb mencatat setidaknya ada tiga relasi positif antara akal dan usul fikih; (1) berperan dalam menghidupkan kembali tradisi berfikir manhaji (metodologis), (2) berperan dalam mereorintasikan kembali manahij (metode) yang dilakukan para ulama, dan (3) berperan dalam membangun dan menghidupkan kembali tradisi ulama' ușuti. Bagi Ali Harb, ketiga relasi ini sekaligus terangkum sebagai kritik nalar atau kritik epistemologi. ${ }^{28}$

Penggunaan akal dalam aktivitas dialektika fikih memang bukanlah hal baru, Imam al-Syāfi'i, Mu'tazilah, Hanāfiyah, Zāhiriyyah, ${ }^{29}$ dan sebagainya. $^{30}$ merupakan intelektual sejarah yang menjadikan usul fikih sebagai pusat teoritisasi aktivitas praksis, teoritisasi perbuatan, logika perilaku, serta metodologi pembacaan dan pengambilan hukum dari nașs. ${ }^{31} \mathrm{Di}$ tangan merekalah tradisi berpikir digerakkan, tradisi akademik dihidupkan. Sehingga,. jika dikategorisasikan secara garis besar, tradisi pola pikir ușuli yang berjalan dalam rentetan sejarah kajian hukum Islam terbagi menjadi dua bentuk, istidlali dan istiqra'i. Kedua pola ini memiliki pebedaan, di samping masingmasing juga memiliki keunggulan.

Pada titik dua pola ijtihad inilah akal memiliki peran aktif. Baik pola istinbat yang mengambil dari dalil (istidlail), ${ }^{32}$ maupun pola istinba! yang mengambil dari fakta kejadian (istiqra'), ${ }^{33}$ sama-sama memainkan peran akal dalam operasionalnya. Namun, peran akal paling dominan terdapat pada pola ijtihad golongan liberatif, yang akhirakhir ini muncul kepermukaan untuk menggeser dua pola ijtihad diatas yang sudah lama eksis. Aliran liberatif ini bahkan memberikan porsi yang sangat besar kepada akal untuk terlibat dalam proses ijtihad dan mengeluarkan hukum. ${ }^{34}$

1. Istidlal (Deduksi).

Dalam tradisi usul fikih, pola analisis istidlali berangkat dari keyakinan adanya keterkaitan yang erat antara bahasa dengan pengetahuan. Substansi sebuah pesan -ajaran- dapat dipahami lewat bahasa yang digunakan. Pola ini dalam menentukan makna sebuah pesan yang di-khitab-kan, biasanya menggunakan instrumen dialektika teks dan analisis (text dialectic and analysis). ${ }^{35}$ Al-Jäbiri memasukkan pola analisis in kedalam episteme bayañ $\overline{1}^{36}$

Dalam istidlal, dialektika teks dan analisis dioperasionalkan dengan membuat himpunan kaidah dan aturan, yang digunakan untuk menafsirkan wacana (khitab) yang terungkap dari teks. Sehingga, penguasaan logika bahasa Arab (mantiq) menjadi tumpuan penting dalam membentuk sistem penalaran yang sistematis. ${ }^{37}$ Peran akal akan terlihat aktif dalam me-linier-kkan berbagai teks agar tersetruktur dalam sebuah argumentasi.

Instrumen dialektika teks dan analisis ini biasanya mengandalkan pendalaman analisis dan penggunaan akal yang baik. Oprasional untuk menemukan hukum biasanya mengandalkan jenis akal meditatif ('aql mu'abir) dan akal 
dialektika ('aql jadali). Akal jenis ini difungsikan untuk mengakumulasikan berbagai kontradiksi teks dalam mendapatkan sebuah persepsi dan pola ketetapan hukum. ${ }^{38}$ Model berpikir akal jenis ini sebenarnya mirip dengan silogisme, $^{39}$ atau logika Aristoteles, ${ }^{40}$ sebagaimana yang sering terlihat dimainkan oleh ulama' tradisionalis. Instrumen akal jenis inilah yang berperan melahirkan qiyās bayāni, ${ }^{41}$ sebagai produk khas dari nalar Arab itu sendiri. ${ }^{42}$

Dengan instrumen ini, maka menurut al-Jābiri -sebagai sebuah kritik-, Imam al-Syāfi'i tidak menciptakan teori qiyas, ia hanya mengembangkan teori qiyās dari logika bahasa teks. ${ }^{43}$ Karena itu, intrumen pengetahuan hukumnya lebih banyak didasarkan pada prinsip 'alaṣl fí al-naṣs là fí al-wäqi'. Sehingga, konstruksi penyelesaiannyapun berkisar pada persoalan petunjuk wacana (dilalat al-khitab).

Dalam keadaan instrumen analisis seperti ini -lanjut al-Jābiri-, akal difungsikan kebanyakan untuk memutarbalikan logika guna menyingkapi batasan-batasan deskriptif, memetakkan esensi, dan memecahkan sebuah identitas. ${ }^{44}$ Persoalan yang ada (al-far') dicari rujukannya pada asl dengan berpegang pada kerja bahasa di atas. ${ }^{45}$ Bisa dibilang aktivitas istidlali nya hanya terorientasi pada ijtihad bayañ $\overline{\text { - }}$ qiyasi ${ }^{46}{ }^{46}$ penggunaan akal sebatas pada hal-hal yang bisa diqiyaskan saja. Akibatnya, ijtihad hampir mirip dengan qiyass, padahal qiyās itu sendiri adalah bagian dari metode ijtihad. ${ }^{47}$ Dengan pola qiyas ini, akal hanya digunakan untuk membentuk (mubtadi') hukum dari naș. $^{48}$

Analisis kategoris akal dalam pola istidlal ini dapat diringkas dalam beberapa runtutan. Pertama, akal dan dua sumber (nașș) menyatu sebagai bahan dasar dalam mengeluarkan hukum. Kedua, akal memiliki posisi penting sebagai analisator guna membangun argumentasi hukum yang tepat, dan sebagai andalan dalam melakukan dialektika teks dan analisis. Ketiga, kendati memiliki porsi yang kecil dalam lingkaran sumber ijtihad, proporsi akal tetap saja diandalkan dalam mengeluarkan hukum yang logis berdasarkan teks yang ada, sehingga hukum yang keluar tidak kontras dengan maksud teks. Keempat, dengan pola istidlal ini, penekanan fungsi umum akal digunakan dalam menemukan hukum (rechtsvinding). Seorang mujtahid dalam pola istidlal ini tidak sedang berusaha membuat hukum, melainkan sedang berusaha menemukan hukum yang terkandung dalam nașs. Karena landasan Mujtahid pada keyakinan bahwa hukum dibuat oleh Tuhan, dan terdapat di dalam firman-Nya (nașș). ${ }^{49}$

Berikut skema akal dalam cara bepikir istidlali/istintaji. Skema ini melingkupi porsi akal, posisi akal dalam kerja operasional dan proporsi akal sebagai sebuah instrumen analsis dalam tradisi ușuti.

\section{Lingkaran Porsi Akal dalam}

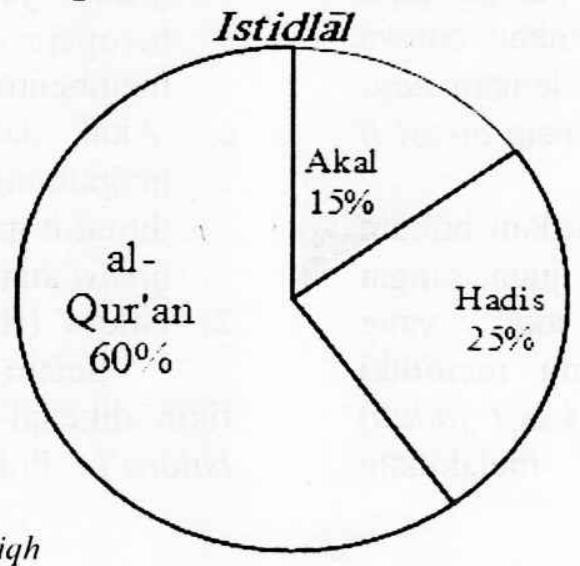




\section{Skema Posisi Akal Secara Operasional dalam Istidläl}

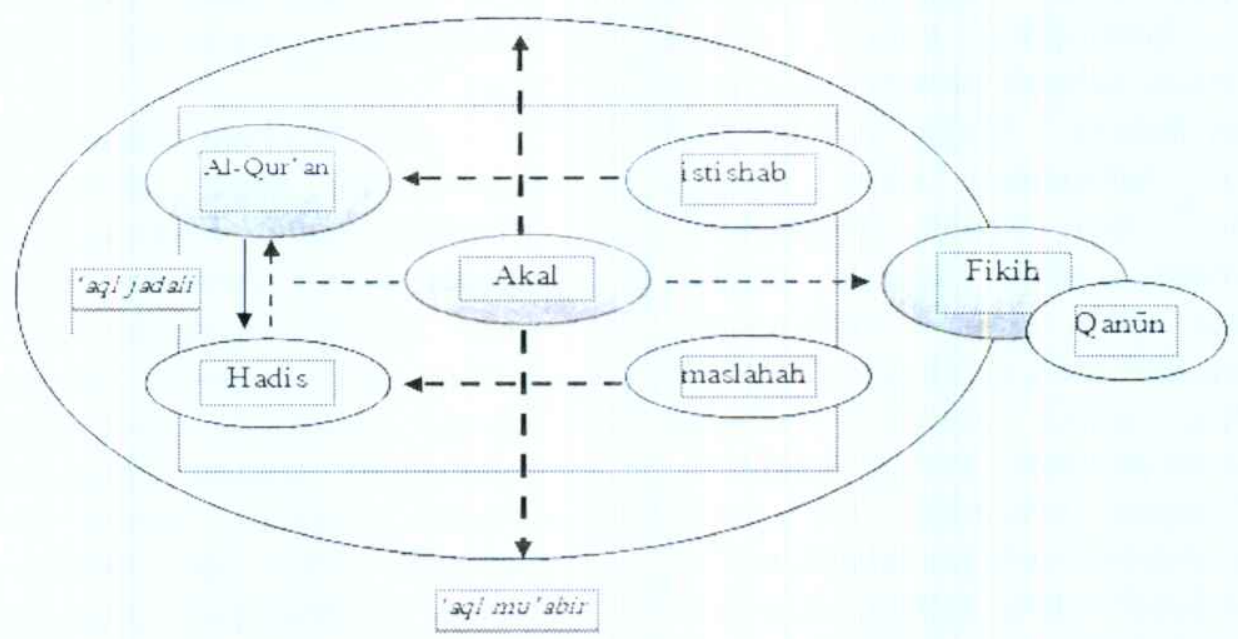

Skema formasi dan proporsi akal sebagai penemu hukum (rectsvinding) Dalam Istidlal

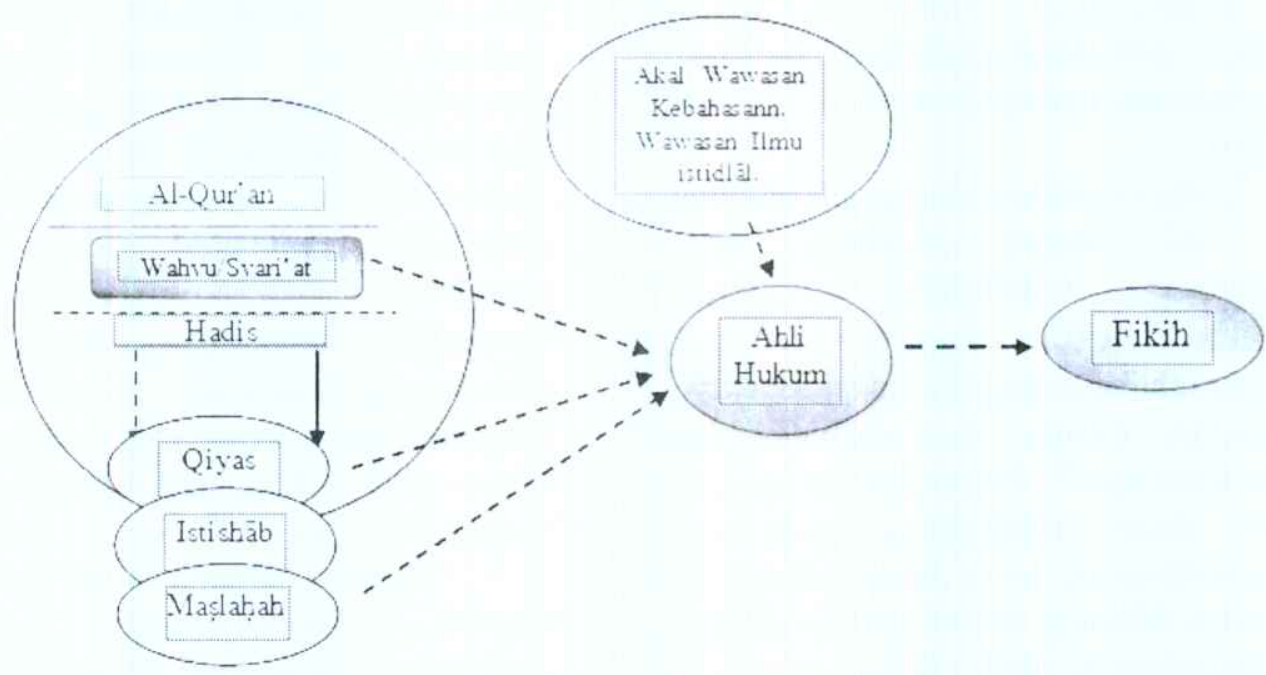

Penjelasan dari skema di atas adalah sebagai berikut:

a. Lingkaran porsi akal menunjukkan lingkaran dengan garis menyatu dan terikat. Artinya, akal dalam pola istidlal ini telah menekankan bahwa ia tidak bisa berjauhan dengan naș serta berpegang pada prinsip al-așl fí al-naș lä fí al-wäqi'.

b. Posisi akal dalam melahirkan hukum dalam pola istidlal ini juga sangat sentral. Dua jenis akal yang digunakan masing-masing memiliki peran. Akal dialektika ('aql jadali) berperan aktif dalam melakukan dialektika teks (nașs), sedangkan akal meditatif ('aql mu'abir) berperan dalam menganalisis dan mendialogkan nașs dengan teori ușuli yang sudah ada. Semua ini beroperasi dalam satu tujuan, membentuk hukum (fikih).

c. Akal dalam menemukan hukum, bergantung pada mujtahidnya. Ia dituntut menguasai teori-teori bayañiqiyasisi atau teori kebahasaan lainnya.

2. Istiqra' (Induktif).

Selain istidlali, dalam tradisi usul fikih dikenal juga dengan pola analisis Istiqra'i. Pola analisis Istiqra' dalam 
tradisi ușuli menekankan penelitian terlebih dahulu guna mendapatkan kebenaran atau kesimpulan sebuah hukum. $^{50}$ Instrumen yang digunakan dalam menemukan hukum adalah eksperimentasi dan penalaran akal. ${ }^{51}$ Dalam proses eksperimentasi, akal digunakan untuk mengamati realitas, menganalisis sebab sebab (idrak al$s a b a b$ ), hingga menghasilkan sebuah pengetahuan/pemahaman. ${ }^{52}$

Al-Jābiri memasukkan analisis

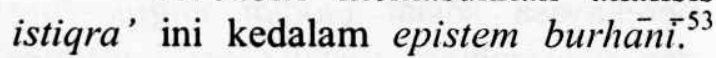
Berbeda dengan epistem bayāni, kebenaran dalam epistem burhäni tidak hanya pemakaian logika secara absah saja, tetapi juga kesesuaian (mutabaqah) antara nalar dengan realitas dan hukumhukum alam. ${ }^{54}$ Beberapa ulama telah mengembangkan analisis istiqra' ini, diantaranya Imam Abū Ishaq al-Syātibi. ${ }^{5 S}$ Sebagaimana pola istidlal di atas, pola istiqra' $i$ juga memainkan akal sebagai instrumen penemuan hukum. Bahkan, porsi akal yang dimainkan lebih besar dari pola analisis istidlati di atas. Dalam tradisi usul fikih yang mengembangkan pola istiqra', ada beberapa jenis, peran dan fungsi akal yang dimainkan didalamnya.

a. Akal Realitas (al-'Aql al-Wäqi 'î)

Akal dalam pola ini sebenarnya sudah terlihat dalam fikih klasik, hanya saja aksentuasinya yang lebih rill diperlihatkan dimasa modern ini, seiring dengan masuknya keilmuan filsafat. $\mathrm{Al}$ 'Aql al-wäi'i merupakan cara berpikir dalam filsafat hukum Islam yang berpegang pada kekuatan natural manusia (indrawi) dan otoritas akal dalam memperoleh pemahaman dan pengetahun, sehingga akal berpungsi sebagai sandaran utama. Instrumen yang digunakan adalah diskursif (bahsliyyah), penelitian dan pengkajian mendalam. ${ }^{56}$ Kekuatan rasio atau akal sangat diandalkan dalam melakukan diskursi/bahsliyyah ini.

Akal dijadikan metode dan mesin sekaligus dalam mengolah realitas/fenomena/kejadian dan teks, maupun hubungan antar keduanya sebagai sumber kajian. Sehingga, simpulan hukum yang dihasilkan memiliki alur metode epistemologi yang jelas, dari observasi empiris dan inferensiasi intelektual. ${ }^{57}$ Secara praksis, buah yang paling nyata dari akal jenis ini adalah lahirnya fikih realitas (figh alwäqi'), seperti fikih jual beli, fikih kedokteran, fikih keluarga, dll. Rumusan fikih ini biasanya yang dikemas, setelah sebelumnya melakukan konfirmasi mendalam dari kutub penelitian lapangan terlebih dahulu dan respon dalam nașs. Jika tidak selalu ditemukan naṣs yang spesifik mengenai realitas yang ingin direspon, disinilah letak kreatifitas sang mujtahid.

Adapun secara teoritis, Muhammad Syahrūr mencontohkan penggunaan akal jenis ini, dalam merekonstruksi dan meredifinisi konsep qiyās yang ada dalam tradisi usul fikih klasik. Menurut Syahrūr -sebagai sebuah kritik-, tidak tepat generasi yang hidup di abad modern ini menganalogikan sesuatu kepada generasi yang hidup di masa Nabi. Apalagi selama ini qiyās selalu dimainkan dari analogi sesuatu yang syāhid (jelas dan ada) kepada sesuatu yang gāib (samar).

Qiyās menurut Syahrūr adalah menemukan hukum baru dengan menganalogikan yang syähid (nyata/jelas) dengan yang syāhid pula. ${ }^{58}$ Artinya, definisi yang benar dari qiyās adalah penerapan sebuah aturan hukum tertentu yang diproduksi pada masa kini (realitas kini) dan kepada masyarakat masa kini pula. Sebagai contoh, pelarangan rokok seharusnya bukan dengan analogi akal qiyas nașs semata, tapi lebih kepada kajian terhadap realitas pasti yakni ilmiah kedokteran. Sehingga analisis memgenai obyek bukan deskripsi mengenai obyek itu sendiri, sebagaimana yang banyak dilakukan dalam istidlal, melainkan analisis yang ditopang illatnya dari analisis kebenaran realitas. ${ }^{59}$ 
Dengan narasi ini, maka akal realitas (aql al-wäqi'i) mendapatkan peran vital dengan dua pertimbangan rasional: pertama, hukum Islam adalah hukum sipil buatan manusia yang disatu sisi mengindahkan kalam Tuhan dan disisi lain mengindahkan realitas sosial. Kedua, hukum Islam bukan syari'at 'aini tetapi syari'at hududi yang membuka lebar kreativitas manusia, ${ }^{60}$ dengan akal sebagai mesinnya.

b. Akal Hermeneutis (al-'Aql al-Ta'wili)

Hermeneutik merupakan salah satu teori interpretasi al-Qur'an. Namun, akal hermeneutik disini tidaklah dimaksudkan menyinggung kearah itu. Akal hermeneutik bisa dimaknai dengan pola pikir yang harus diperhatikan sebelum dan ketika melakukan ijtihad. Hassan Hanafi memberikan tiga tahap kerja hermeneutis dalam ijtihad: (1) kesadaran historis, dengan mematangkan pengetahuan klasik teks. (2) kesadaran eidetis, dengan mempersiapkan diri untuk interpretasi hermeneutik, dan kesadaran praksis, dengan berusaha mentransformasikan wahyu dari ide normatif ke gerakan realitas/sejarah. Dalam bentuk akal sebagai sebuah kesadaran dan pemikiran inilah yang kemudian melahirkan "fikih kiri". 61

Dalam usul fikih, instrumen akal jenis ini bergerak dengan bantuan metode genetika/historis dan metode dialektika. ${ }^{62}$ Berbeda dengan pola dialektika dalam istidlali, dialektika dengan akal jenis ini dalam pola istiqrä' $i$ ini akan melakukan melakukan kajian didalam dan diluar teks sekaligus. Sehingga, poin-poin bahasan seperti: konteks tekstual (siyäq an-nasss), konteks pembicaraan (siya $\vec{q}$ al-khitab), konteks kondisi signifikan (siyaq alhal), ${ }^{63}$ menjadi elemen yang simetris dan terikat. Elemen ini selain dibaca dengan teliti, juga dibaca dengan kritis. Karena itu, al-'Aql al-ta'wili disebut juga 'aql alnäqid (akal kritis). Para pemikir yang menggunakan domain akal ini disebut dengan the progressive ijtihadis. Yakni, pola ijtihad yang tidak terlalu asyik memainkan teks semata, namun juga bermain dengan baik pada landasan konteks dalam melahirkan kontekstualisasi hukum Islam. ${ }^{64}$

c. Akal Filsafat (al-'Aql al-Falsafi)

$$
\text { Akal filsafat dalam bahasa }
$$

sederhana difahami dengan model penalaran hukum dengan berpegang pada filsafat. Filsafat sebagai pemikiran hukum berangkat dari keyakinan bahwa pengejawantahan hukum Islam sebagai pengendali masyarakat (social control), perekayasa sosial (social engineering) dan pensejahtera sosial (social welfare) telah memberikán akal fungsi penuh untuk mengadaptasikannya dengan lingkungan baru. ${ }^{65}$ Sehingga, akal mendapatkan tempat utama dalam membangun realitas fiqh yang lebih baik dalam kurun tertentu.

Akal jenis ini yang terbaru dikembangkan ơleh Jasser Auda, dalam mereorientasikan" konsep maqașid alsyarïah. Módel penalaran ini menegaskan fungsi dan peran akal tidak untuk mengukuhkan otoritas teks, melainkan melakukan analisis dan menguji secara:terus menerus sebuah konklusi hukum' secara dialektis. ${ }^{66}$ Bisa dikatakan episteme ini lebih berorientasi pada otoritas akal (sultân al-'aql), dengan tiga intrumen penalaran, induksi (alistiqra), inferensia (al-istintaj), direksi hukum (al-maqāsid). ${ }^{67}$

Sebagaimana jenis sebelumnya, akal filsafat juga melakukan dailektika atau penyesuaiản, namun penyesuasian yang dilakukañ bukan dengan teks, melakinkan antara akal itu sendiri dan realitas (mutaba'qah bayn al-'agl wa alwāqi'), atau antara form berpikir (keilmuan) dan pertimbangan aspek practical life. Dengan pola akal seperti ini, maka cara berfikir dalam membuat hukum tidak hanyya secara bayāni-qiyāsi, namun juga : ru'yah takāmuliyyah (pandangan intergral). ${ }^{68}$ Oreintasi seperti ini dalam tradisi usul fikih, disebut juga dengan istilah ijtihad al-istișlahi ${ }^{69}{ }^{69}$ 
Dalam akal filosofis, untuk melahirkan sebuah hukum, instrumen analisi akal dibangun atas tiga poin besar yakni: ketelitian (ra'yu al-bașāriyyah), ketajaman pengetahuan ilmiyah ( $\mathrm{ra}^{\prime} \mathrm{yu}$ al'ilmiyyah) dan keyakinan (al$i^{\prime}$ 'tiqadiyyah). ${ }^{70}$ Ketiga instrumen ini menguatkan posisi akal sebagai penentu dalam melahirkan sebuah hukum melalui pemahaman dan kajian yang menyatu (tawhid) dan holistik (kulli). Sebagimana yang digagas oleh Hasan at-Turabi, ${ }^{71}$ dan Jasser Auda. ${ }^{72}$

Sebagai simpulan, analisis kategoris akal dalam pola istiqra' ini bisa dicatat dalam beberapa hal. Pertama, akal dan dua sumber (nașș) terpisah namun membentuk lingkaran sebagai bahan dasar dalam mengeluarkan hukum. Kedua, akal memiliki posisi penting sebagai mesin dalam melakukan diskursif kepada realitas, sosial, dan sebagainya. Akal juga sebagai andalan dalam melakukan dialektika kajian diluar teks, seperti: konteks tekstual (siyāq al-nașs), konteks pembicaraan (siyāq al-khitä), konteks kondisi signifikan (siyäq al-hal). Ketiga, besarnya porsi yang dimiliki akal dalam lingkaran sumber ijtihad, membuat proporsinya menjadi andalan dalam mengeluarkan hukum yang humanis berdasarkan realitas yang ada dan teks yang mewadahi. Keempat, dengan pola istiqra' ini, penekanan fungsi umum akal digunakan sebagai pembentuk dan pencipta hukum (rectsvorming). Apakah dengan melakukan proses konkretisasi peraturan hukum yang bersifat umum dalam nașs terhadap peristiwa-peristiwa konkret yang terjadi di masyarakat, ataukah secara langsung mengeluarkan hukum yang sama sekali belum ada. ${ }^{73}$

Berikut skema akal dalam cara berfikir istiqra' $i$. Skema ini melingkupi porsi akal, posisi akal dalam kerja operasional dan proporsi akal sebagai sebuah instrumen analsis.

\section{Lingkaran Porsi Akal dalam Istiqra'}

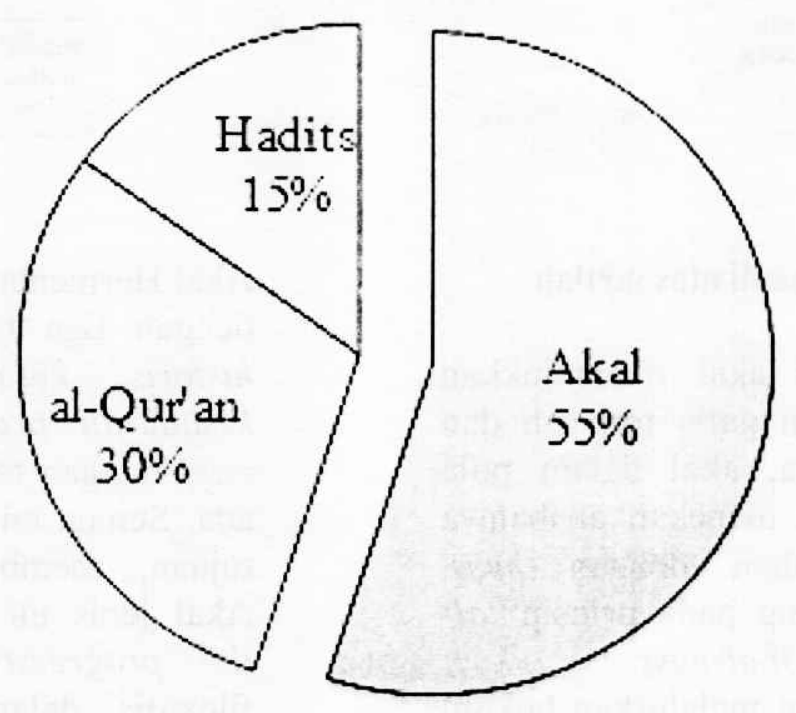




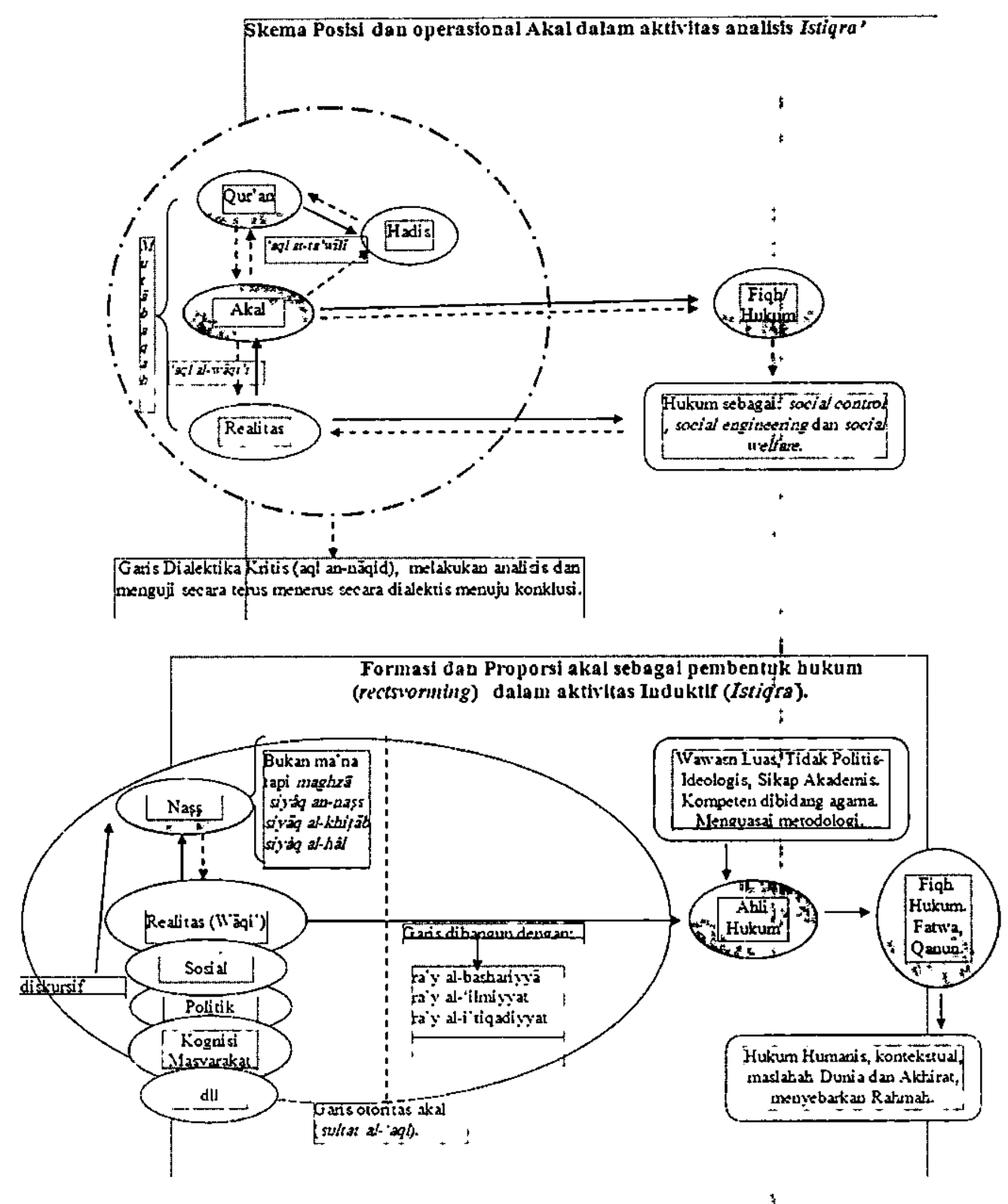

Penjelasan dari skema di atas adalah sebagai berikut:

a. Lingkaran porsi akal menùnjukkan lingkaran dengan garis terpisah dan berjarak. Artinya, akal dalam pola istigra' ini telah menekankan bahwa ia bisa berjauhan dengan nașs. Dengan berpegang pada prinsip " $a l$ aṣl fi al-wäqi' läfí al-nașs.

b. Posisi akal dalam melahirkan hukum dalam pola istiqra' ini juga sangat penting, bahkan ia memiliki otoritas tinggi. Tiga jenis akan yang digunakan masing-masing memiliki peran. Akal Realitas (al-'Aql alWaqqi'i), berperan aktif dalam melakukan diskursif (bahsliyyah).
Akal Hermerieutis (al-'Aql al-Ta'wili) dengan tiga tahap kerja kesadaran historis, kesadaran eidetis, dan kesadaran praksis berperan dalam nașs dengan teori ușuli yang sudah ada. Semua ini beroperasi dalam satu tujuan, membentuk hukum (figh). Akal jenis ini diperankan oleh para the progressive ijtihaditsts. Akal filosofis, dalam fungsi melakukan dailektika atau penyesuaian (mutabaqah bayn al-'aql wa alwäqi) guna melahirkan hukum yang humanis dari sebuh pandangan yang terintergral (ru'yah takämuliyyah).

c. Dalam pola istigra'i ini, akal berfungsi sebagai pembentuk dan 
pencipta hukum (rectsvorming). Sehingga, seorang Mujtahid dituntut menguasai teori sosial dan agama dengan baik.

\section{Akal Sebagai Titik Tekan Ijtihad}

Akal dan posisinya dalam teknik ijihad dari uraian diatas dapat dibedakan menjadi tiga tipe: (1) al-ijtihäd al-bayani, yakni ijtihad yang berhubungan dengan penjelasan yang berada didalam sumber hukum, al-Qur'an dan Sunnah. (2) alijtihäd al-qiyasi, yakni ijtihad untuk menyesesaikan persoalan yang tidak ada ketentuannya dalam sumber hukum, dan ulama' menyelesaikannya secara qiyās. Ijtihad ini oleh Abdullah Saeed diorientasikan pada text-based ijtihad, ${ }^{74}$ dengan akal digunakan sebagai penunjang. (3) al-ijtihäd al-istișlan̄i, yakni ijtihad yang menggunakan akal dan tidak menngunakan sumber utama secara spesifik, berpegang pada ruh asy-syari' at (maghza) yang ditetapkan dalam semua ayat al-Qur'an dan hadis secara eksplisit maupun implisit. ${ }^{75}$ Ijtihad model inilah yang disebut progresif oleh Abdullah Saeed dengan mengorientasikan pada context-based ijtihad. ${ }^{76}$ Ketiga ijtihad ini jelas memiliki tekanan yang sama ketika digunakan oleh manusia. Dan menjadi bagian dari unsur fiqh dengan sifat skeptis-subyektif. Dan ketiga jenis ijtihad ini jelas tidak kebal dari kritikan. ${ }^{77}$

Setelah mencermati hubungan nașs dengan akal, hubungan nașs dengan tradisi atau perkembangan sosial dan syarat ijtihad, maka cara kerja ijtihad di atas dapat diterapkan dengan mengikuti dua kerangka konseptual. Pertama, gerak dari atas ke bawah (min al-a'lâ ilâ aladnâ), dengan memahami nașs secara kolektif, partikular dan universal, untuk diambil suatu kesimpulan hukum. Kemudian hukum tersebut diproyeksikan kepada kasus-kasus atau gejala-gejala yang terjadi dalam masyarakat.

Kedua, kerangka konseptual gerak dari bawah ke atas (min al-adnâ ilâ al$a^{\prime}(\hat{a})$, dengan mempelajai kasus-kasus atau gejala sosial secara mendalam, untuk ditarik suatu kesimpulan hukum tentatif. Kemudian hukum tentatif itu dikonfirmasikan dengan nașs hukum. Bila ada unsur-unsur yang bertentangan, maka nașs tersebut memberikan nilainilai (filosofis) yang sesuai dengan tujuan-tujuan umum syarî'ah.

Kedua konsep ini jelas memperhitungkan eksistensi akal walau dengan kadar yang berbeda. Eksistensi dan peran akal apakah akal sebagai wacana atau metode, ${ }^{78}$ diintrumentakan oleh asy-Syâtịî dengan beberapa premis. Pertama, seandainya dalîl-dalîl syara' tidak mengakui peran akal, maka dalîl hukum itu bukanlah petunjuk hukum syara' bagi para hamba yang berakal. Kedua, seandainya dalîl itu tidak mengakui akal maka berarti akan mengarah kepada pembebanan sesuatu hukum yang tidak mampu dilaksanakan oleh manusia. ${ }^{79}$ Ketiga, berdasarkan penelitian mendalam, tempat pembebanan hukum itu adalah akal, tanpa akal maka tidak ada beban. ${ }^{80}$

\section{E. Penutup}

Nașs adalah wahyu Tuhan yang sifatnya mutlak, sedangkan akal adalah alat berpikir manusia yang sifatnya nisbi dan digunakan untuk penalaran. Akal memiliki peran dalam membimbing pemahaman (undestanding), memberikan persepsi (perception) dan melakukan pengamatan (cognition). Hal ini tentu baik untuk direlasikan dengan usul fikih. Relasi positif antara akal dan usul fikih setidaknya dapat dicatat pada tiga hal; pertama, dalam menghidupkan kembali tradisi berpikir manhaji (metodologis), kedua dalam mereorintasikan kembali metode (manahij) yang dilakukan para ulama, dan ketiga membangun kembali tradisi ulama' usuliti.

Ada dua metode penemuan hukum Islam yang masih berkembang sampai sekarang, yakni istidlat (deduksi) dengan gaya istinbat mengambil dari dalil, dan istiqra' (induksi) dengan gaya 
istinbat mengambil dari fakta kejadian. Dalam deduksi (istidlal), porsi akal sangat kecil, yakni: Qur'an 60\%, hadis $25 \%$ dan akal $15 \%$. Akal memiliki peran atau posisi memberikan penjelasan yang linier (argumentatif), dengan dua jenis akal yakni akal meditatif ('aql mu'abir) dan akal dialektika ('aql jadali). Dalam deduksi proporsi atau penggunaan akal kebanyakan hanya untuk analogi, dan diposisikan membentuk (mubtadi) hukum dari nașs dan serta sebagai penyempurna (al-mutammimah) saja.

Adapun dalam induksi (istigra'), akal memiliki porsi yang aling besar, yakni: Akal 55\%, Qur'an 30\%, hadis $15 \%$. Dalam istiqra', akal diproporsikan dalam proses eksperimentasi, untuk mengamati realitas, menganalisis sebabsebab. Terdapat beberapa metode dalam

\section{Catatan akhir:}

1 Haidar Bagir, "Akal adalah Rasul dalam Diri Manusia" dalam www.islamlib.com, diakses 5 Agustus 2015.

2 Abdullah Saeed, Islamic Thought an Introduction (New York: Rouledge, 2006), hlm, 43-44.

3 Ali Harb, Relativitas Kebenaran Agama: Kritik dan Dialog, terj. Umar Bukhory (Yogyakarta: IRCiSoD, 2001), hlm. 16-17.

4 M. Atho' Mudzhar, Membaca Gelombang Ijtihad: Antara Tradisi dan Liberasi (Yogyakarta: Titian Ilahi press, 1998), hIm. 98.

${ }^{5}$ Muhammad Roy, Dekonstruksi Teori Hukum Islam: Kritik Terhadap Konsep Mașlahah Najamuddin al-Tiffi (Yogyakarta: Kaukaba, 2014), hlm. 142-143. M. Atho' Mudzhar, Membaca Gelombang ljtihad, hlm. 110. Setidaknya tiga kelompok usuliyūn yakni: ahl alhadis 1 ahl al-ra'yi dan mutakallimin merupakan bukti sejarah mengenai membuminya penalaran dalam melahirkan hukum Islam. Abdul Salam Arief, "Kontribusi al-Syāfi'i Terhadap Jurisprudensi Islam", Dalam Jumal al-Jāmi'ah no. 56, tahun 1994, hlm. 110.

- Haidar Bagir, "Akal adalah Rasul dalam Diri Manusia" dalam www.islamlib.com, diakses 05 Agustus 2015

7 Pentingnya akal dalam ijtihad

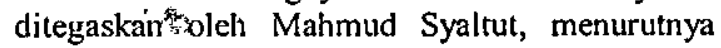
akal sebagai alat atau metode penalaran (turiqq aladillah) dalam hukum Islam sudah mendapatkan istigra' yang menguatkan peral akal yaitu al-'aql al-wagi't (akal realitas), al-'aql al-ta'wili (akal hermeneutis), dan al-'aql al-falsafi (akal filosofis). Dalam induksi, akal memiliki pungsi dalam membentuk sebuah hukum (rectsvorming) dari ketidak adaan berkat doronagn realitas.

Ada bebęrapa formulasi mengenai peran akal daląm epsitemologi hukum Islam. Pertama akal memainkan peran yang baik dalam istinbath, kedua akal memiliki kemungkinan untuk menjadi pencipta hukum, ia bisa membedakan baik dan buruk ketiga banyak posisi akal yang bersifat konfirmatif kepada teks, tidak tunduk lansung desebabkan keterbatasan teks yang ada. Karena itu, maka indepedensi akal dalam berfikir dan menemukan hukum perlu dijaga, karena ia memiliki kemampuan untuk itu.

posisi yang signifikan dalam membentuk 'sebuah jalan' berfikir. Akal memiliki posisi dan membentuk model, warna, corak bahkan bangunan hukun: yang beragam. Mahmud Syaltut, Islam: 'Agidah wa Syariah (Mesir: Dar al-Qaläm, 1966), hlm. 56. Lihat juga Hadi Putra Wirman, "Problematika Pendekatan Analogi (Qiyass) dalam Penetapan Hukum Islam: Telaah atas Pemikiran Ibn Hazm dan Ibn Qoyyim alJawziyah ", dalam Jurnal Asy-Syir'ah:. Jurnal Syari'ah dan Hukum, Vol. 47, No. 1, Juni 2013, hlm. 31-32.

${ }^{8}$ Abdul Salam Arief, "Kontribusi asySyäfi $r$, hlm. 114.

9 Wahbah' al-Zuhayli, Ușil al-Figh alIslāmi (Beirut: Dār al-Fikr, 1998), l: 417. Muhammad Aiwi al-Maliki, Syari'atullah alKhäidah: Dirāsah fi Tärikh Tasyri' Ahkān wa Maz|ahib al-Fugah'a' al-A 'läm (Makkah, tnp, t.t.), hlm. 12. 'Abdul Wahhäb Khallāf, 'Ilm Ușul alFigh (Beirut: Där al-Fikr, 1998), hlm. 21-22. Abdullah Saeed, Islamic Thought, hlm. 48-49.

10 Amin Syukur, "Keseimbangan Perkembangan Tàsawuf dan Fiqh di Indonesia" dalam Noor Ahmidd, dkk., Epistemologi Syara': Mencari Formàt Baru Figh Indonesia (Yogyakarta: Pustakka Pelajar, 2000), hlm. 11-27. "M.ll Abed al-Jabiri, Post Tradisonalisme IIslam, terj. Ahmad Baso (Yogyakarta : LKiS, 2000), hlm. 28. Ali Harb, Relativitas Kebenaran Agama, hlm. xxi.

12 Kategoris yang penulis maksdukan adalah dalam serise deskriptif. Kata 'deskripsi' secara bahasa bisa 'diartikan dengan menguraikan, 
memaparkan atau menggambarkan sesuatu secara jelas apa adanya. Adapun kata "analisis" secara bahasa bisa diartikan sebagai penyelidikan terhadap suatu peristiwa (teks atau praktik) untuk mengetahui keadaan yang sebenarnya, dari penyelidikan dan penguraian bagian itu (item dalam objek) dapat diperoleh pengertian yang tepat dan pemahaman arti keseluruhan. Adapun kritis berarti bersifat tidak dapat lekas percaya dan selalu berusaha menemukan kesalahan atau kekeliruan dengan bekerja pada ketajamann penganalisisan dan mencermati bagian-bagian kecil, yang mungkin tidak bisa dijangkau dengan deskripsi semata. Tim Penyusun, Kamus Besar Bahasa Indonesia (Jakarta: Pusat Bahasa Pendidikan Nasional, 2008), hlm. 59, 347, 761.

${ }^{13} \mathrm{Ibid}$., hlm. 25.

${ }^{14}$ Ahmad Warson Munawwir, Kamus alMunawwir (Surabaya: Pustaka Progressif, 1997), hlm.

15 Ibnu Manzūr, Lisān al-'Arab (Beirut: Dār al-Kutb al-'Ilmiyyah, 1996), VIII: 458.

${ }^{16}$ Ibrahim Mustafá, al-Mu'jam al-Wasít (Ttp.: Mustafa al-Babi al-Halabi, t.t.), I: 141.

${ }^{17}$ Ibid.

${ }^{18}$ Tim Penyusun, Kamus Besar, hlm. 25-

26.

19 Yusuf al-Qardhawi, Al-Qur'an Berbicara Tentang Akal dan Ilmu Pengetahuan, terj. Abdul Hayyie Al-Kattani, dkk. (Jakarta: Gema Insani, 1998), hlm. 19.

20 Harun Nasution, Akal dan Wahyu dalam Islam (Jakarta: UI Press, 1986), hlm. 7.

${ }^{21}$ Ibid., hlm. 39.

${ }_{22}^{22}$ Al-Qardhawi, Al-Qur'an, hlm. 33.

23 Harun Nasution, Akal dan Wahyu, hlm. 45 .

${ }^{24}$ Ibid., hlm. 48.

25 Haidar Bagir, "Akal adalah Rasul dalam Diri Manusia" dalam www islamlib.com.

${ }^{26}$ Muhammad Abū Zahrah, Usuit al-Fiqh (Kairo: Dār al-Fikr al-‘Arabi, 1958), hlm. 3. Ali Harb, Relativitas, hlm. xxiii.

${ }^{27} \mathrm{Ibid}$.

${ }^{28}$ Dengan makna positif, kritik terhadap metodologi yang melahirkan suatu ilmu, kritik dalam konteks ini ditujukan pada bangunan keilmuan hukum Islam yang dilihat sebagai produk sejarah pemikiran keagamaan biasa yang mempuyai dimensi relativisme. Ali Harb, Relativitas, hlm. xxiii.

${ }_{29}$ Amri Siregar, Ibn Hazm: Metode Zahiri dalam Pembentukan Sumber Hukum Islam (Yogyakarta: Belukar, 2009), hlm. 78.

${ }^{30}$ Aksin Wijaya, Teori Interpetasi Ibn Rusyd: Kritik Ideologis-Hermeneutis (Yogyakarta, LKiS, 2009), hlm. 277-278. Bandingkan juga ulasan Abū Ishāq Ibrāhìm ibn Mūsā asy-Syātibī, al-Muwājaqāt fí Ușul al-
Syari'ah (Beirut: Dār al-Kutub al-'Ilmiyah, t.t.), II: 391.

31 Anjar Nugroho, "Fikih Kiri: Revitalisasi Ushul Fiqh Untuk Revolusi Sosial", dalam jurnal Al-Jami 'ah, Vol. 43, No. 2, Tahun 2005/1426 H, hlm. 428.

32 Taha Jabir al-Alwani, Metodologi Hukum Islam Kontemporer, terj. Yusdani (Yogyakarta: UII Press, 2001), hlm. vi. Muhammad Roy, Ushul Figh Mazhab Aristoteles: Pelacakan Logika Aristoteles dalam Qiyas Ushul Figh (Yogyakarta: Safira Insani Press, 2004), hlm. 186-187.

$$
{ }^{34} \text { Ibid. } \text { Anjar Nugroho, "Fikih Kiri", hlm. }
$$
428-429.

${ }^{35}$ Muhammad 'Ábid al-Jābirī, Bunyah al-'Aql al-'Arabi; Dirâsah Tahliliyyah Naqdiyyah li al-Nuzum al-Ma'rifah $f i$ al-Tsaqafah al'Arabiyyah, cet. 3 (Beirut: al-Markaz al-S|aqafi al-'Arabi, 1993), hlm. 17.

${ }^{36}$ Ibid., hlm. 556.

${ }^{37}$ Muhammad 'Ábid al-Jābirì, Takwin al-'Aql al-'Arabi, cet. 4 (Libanon: Markaz Dirāsāt al-Wahdah al-'Arabiyah, 1989), hlm. 150.

38 Muhammad Arkoun, Membedah Pemikiran Islam, terj. Hidayatullah (Bandung: Pustaka, 2000), hlm. 31-32.

39 Hadi Putra Wirman, "Problematika Pendekatan Analogi ", hlm. 42.

40 Akh. Minhaji "Ushul Fiqh dan Perubahan Sosial Dalam Persfektif Sejarah", dalam Amin Abdullah, dkk.Mencari Islam: Studi Islam Dengan Berbagai Pendekatan (Yogyakarta: Tiara Wacana, 2000), hlm. 71.

${ }^{41}$ Muhammad Roy, Ushul Figh, hlm. 115-116. Bandingkan dengan ulasan Jaih Mubarok dalam Jaih Mubarok, Metodologi Ijtihad Hukum Islam (Yogyakarta: UII Press, 2002), hlm. 3-5.

42 Muḥammad 'Ábid al-Jābirì, Bunyah, hlm. 560-561.

${ }^{43}$ Al-Jābiri, Takwinn, hlm. 124.

${ }^{44}$ Ali Harb, Relativitas, hlm. 20-21.

${ }^{45}$ Al-Jābirì, Takwin, hlm. 56.

${ }^{46}$ Muhammad Salām Mazkkūr, al-Ijtihād fí Tasrí al-Islämí (Kairo: Dār an-Nahḍah al'Arabiyah, 1984), hlm. 42-45. Lihat juga Jaih Mubarok, Metodologi, hlm. 8.

47 Sulaiman al-Kumayi, Inilah Islam: Telaah Terhadap Pemikiran Hasbi AshShiddiqieqy Dalam Bidang Tafsir, Feminisme, Teologi, Neosufisme, dan Gagasan Menuju Fiqh Indonesia (Semarang: Pustaka Rizki Putra, 2006), hlm. 255.

${ }^{48}$ La Jamaa, "Konsep Ta'abbudi dan Ta'aqquli dan Implikasinya Terhadap Pengembangan Hukum Islam", dalam Jurnal AsySyir'ah: Jurnal Syari'ah dan Hukum, vol. 47, no. 
1, Juni 2013, hlm. 16. Jaih Mubarok, Metodologi, hlm. 98 .

49 'Abd al-Wahab Khalläf, 'Ilm Ușul alFigh (Mesir; Dār al-Qalām, 1990), hlm. 167.

${ }^{30}$ Istiqra' ini memiliki beberapa arti. Pertama, untuk penelitian terhadap nașs-nașs hukum, seperti meneliti nasss-nașs dalam upaya menetapkan tujuan-tujuan hukum Islam. $A /$ istiqra' juga berlaku penelitian terhadap partikular-partikular makna nașs, untuk kemudian ditetapkan suatu hukum umum. Kedua, al-istiqra' digunakannya untuk penelitian terhadap hukumhukum spesifik (far'iyah), dengan berdasarkan metode al-istiqra' atau penelitian induktif terhadap hukum-hukum spesifik, Ketiga, alistiqra'digunakannya untuk melakukan penelitian terhadap realitas sejarah penerapan hukum dan kaitannya dengan tradisi masyarakat. Dengan berdasarkan penelitian induktif terhadap faktorfaktor tradisi (al-istiqra' al-'adi). Duski, "Metode Penetapan Hukum, hlm. 199-200.

${ }^{51}$ Al-Jābirî, Takwin, hlm. 22-23.

52 Al-Jābiri, Bunyah, hlm. 398.

${ }^{53}$ Ibid., hlm. 383.

${ }^{54}$ Al-Jābirì, Takwin, hlm. 22-23.

${ }^{55}$ Dengan dua gagasan besarnya yakni $a l-$ istiqra' al-ma'nawi dengan mempertimbangkan qarain ahwal (indikasi-indikasi keadaan), baik yang di-nașs -kan (manquiah) maupun yang tidak di-nașs-kan (gairu manqulah). Kedua adalah alistiqra' al-'adi yakni melihat faktor-faktor tradisi terbentuknya sebuah hukum. Abū Ishāq lbrähīm ibn Mūsā asy-Syătibì, al-Muwäfaqāt, Il: 5, 39, 228.

56 Zubaedi, "Membangun Fiqh Yang Berorientasi Sosial: Dialektika Fiqh Dengan Realitas Empirik Masyarakat", dalam al-Jami'ah, Vol. 44, No. 2, Tahun 2006, hlm. 440.

${ }^{57}$ Al-Jābiri, Naqd al-'Aql, hlm. 56-71.

${ }^{58}$ Muhammad Syahrūur, al-Kilab wa alQur'än: Qirä'äh al-Mu'așirah (Damaskus: Där al-Ahalli, 1991), hlm. 581-582.

59 Ibid., hlm. 581-582. Lihat juga penjelasan mengenai konsep ijtihad Muhammad Syaḥrūr dalam Muhammad Roy, Dekonstruksi Teori Hukum Islam, hlm. 68-69.

${ }^{60}$ Roy, Dekonstruksi, hlm. 59.

61 Hasan Hanafi, Islamologi I: Dari Teologi Statis ke Anarkis, terj. Miftah Faqih (Yogyakarta: LKiS, 2003), hlm. 160. Anjar Nugroho, "Fikih Kiri", hlm. 445.

62 Tăhā Jäbir al-Alwani, Metodologi Hukum Islam, hlm. Vi.

${ }^{63}$ Nashr Hāmid Abü-Zayd, Nagd alKhitab al-Dini (Kairo: Sinā al-Nasyr, 1994), hlm. 219.

${ }^{64}$ M. Arfan Mu'ammar, "Islam Progresif dan Ijtihad Progresif: Membaca Gagasan Abdullah Saeed", dalam M. Arfan Mu'ammar (dkk.), Studi Islam Persfektif Insider/Outsider (Yogyakarta, IRCiSoD, 2013), hlm. 357.

${ }^{65}$ Pujiono, Hukum Islam dan Dinamika

Perkembangan ". Masyarakat: Menguak

Pergeseran Prilaku Kaum Santri, (Jember: STAIN Jember Preșs, 2011), hlm. 60.

${ }^{66}$ M. Amin Abdullah "Al-Ta'wil al-

"Ilmi; Ke Arah Perubahan Paradigma Penafsiran

Kitab Suci," dalami jurnal al-Jämi'ah, No. 39,

Tahun 2001, hlm. 379.

${ }^{67}$ Al-Jābiri, Bunyah, hlm. 567.

${ }^{68}$ Ali Harb, Relativitas, hlm. 49.

${ }^{69}$ Muhạmmad Salām Mazlkūr, al-Jjtihäd,

hlm. 42-45. Lihat juga Jaih Mubarok, Metodologi Ijtihad Hukum Islam, hlm. 8.

${ }^{70}$ Jaih Mubarok, Metodologi, hlm. 95.

${ }^{7}$ Mohammad Darwis, "Maqāṣid asySyariah dan Pendekatan Sistem Dalam Hukum Islam Persfektif Jasser Auda", dalam M. Arfan Mu'ammar (dkk.), Studi Islam Persfektif Insider/Outsider, (Yogyakarta: IRCiSoD, 2013), hlm. 407.

${ }^{2}$ Ibid.

${ }^{73}$ Khallaf,"Ilm Usull al-Fiqh, hlm. 167.

${ }^{74}$ M. Arfan Mu'ammar, "Islam Progresif dan ljtihad Progresif", hlm. 361.

${ }^{75}$ Mazkür, al-ljtihäd, hlm. 42-45. Lihat juga Jaih Mubarok, Metodologi, hlm. 8.

${ }^{76}$ Mu'ammar, "Islam Progresif", hlm.

361.

${ }^{7}$ Al-Alwąnin, Melodologi, hlm. vii.

${ }^{78}$ Pembedanan "wacana" dan "metode" sebenarnya didasarkan pada analisis al-Jäbiri yang membagi pemikiran menjadi dua yakni pemikiran dari pemikiran sebagai isi (wacana) dan pemikiran sebagai alat (metode). Pemikiran sebagai wacana adalah sekumpulan pendapat dan pemikiran yang dilahirkan oleh pemikiran sebagai alat (metode). Jika dikaitkan dengan syari'at, maka bisa dicontohikan mengenai akhlak, doktrin keyakinan dan ajaran madzhab, serta pemikiran lainnya yang berkaitan dengan pandangan manusia terhadap sesuatu. Adapun pemikiran sebagai alat (metode) berfungsi memproduksikan pemikiran-pemikiran, baik pemikiran yang diproduksi dalam ķerangka internal ideologi, atau bahkan kerangka internal pengetahuan. Aksin Wijaya, Nalar Kritis Epistemologi Islam: Membincang Dialog Krilis Para Kritikus Muslim: Al-Ghazali, Ibnu Rusyd. Thaha Husein dan Abid Al-Jabiri (Yogyakarta: Nadi Pustaka, 2012), hlm. 14.

79 Duski, "Metode Penetapan Hukum", hlm. 127-128.

${ }^{80}$ Ibid. 


\section{DAFTAR PUSTAKA}

Abū Zahrah, Muhammad. Ușul al-Fiqh. Kairo: Dār al-Fikr al-'Arabi, 1958.

Abdullah, M. Amin. “Al-Ta'wil al-'Ilmi: Ke Arah Perubahan Paradigma Penafsiran Kitab Suci," dalam jurnal al-Jämi'ah, No. 39, Tahun 2001.

Al-Alwani, Taha Jabir. Metodologi Hukum Islam Kontemporer, terj. Yusdani. Yogyakarta: UUI Press, 2001.

Arief, Abdul Salam. "Kontribusi alSyāfi'i Terhadap Jurisprudensi Islam", Dalam Jurnal al-Jämi'ah, No. 56, Tahun 1994.

Arkoun, Muhammad. Membedah Pemikiran Islam, terj. Hidayatullah. Bandung: Pustaka, 2000.

Darwis, Mohammad. "Maqāṣid alSyariah dan Pendekatan Sistem Dalam Hukum Islam Persfektif Jasser Auda", dalam M. Arfan Mu'ammar (dkk.). Studi Islam Persfektif Insider/Outsider. Yogyakarta: IRCiSoD, 2013.

Hanafi, Hasan. Islamologi I: Dari Teologi Statis ke Anarkis, terj. Miftah Faqih. Yogyakarta: LKiS, 2003.

Harb, Ali. Relativitas Kebenaran Agama: Kritik dan Dialog, terj. Umar Bukhory. Yogyakarta: IRCiSoD, 2001.

Ibnu Manzūr. Lisān al- 'Arab. Beirut: Dār al-Kutb al-'Ilmiyyah, 1996.

Al-Jābiri, Muhammad 'Ābid. Bunyah al'Aql al-'Arabi; Dirāsah Tahliliyyah Naqdiyyah li alNuzüm al-Ma'rifah fi al-S|aqafah al-'Arabiyyah. Beirut: al-Markaz al-S|aqafi al-'Arabi, 1993.

- Takwin al-'Aql al-'Arabi.

Libanon: Markaz Dirāsāt al-Waḥdah al'Arabiyah, 1989.
. Post Tradisonalisme Islam, terj. Ahmad Baso. Yogyakarta: LKiS, 2000.

Khallāf, Abdul Wahhāb. Ilm Uşûl alFiqh. Beirūt: Dār al-Fikr, 1998.

. 'Ilm Ușul al-Fiqh. Mesir: Dār al-Qalām, 1990.

Al-Kumayi, Sulaiman. Inilah Islam: Telaah Terhadap Pemikiran Hasbi Ash-Shiddiqieqy Dalam Bidang Tafsir, Feminisme, Teologi, Neosufisme, dan Gagasan Menuju Fiqh Indonesia. Semarang: Pustaka Rizki Putra, 2006.

La Jamaa, “Konsep Ta'abbudi dan Ta'aqquli dan Implikasinya Terhadap Pengembangan Hukum Islam", dalam Jurnal Asy-Syir'ah: Jurnal Syari'ah dan Hukum, Vol. 47, No. 1, Juni 2013.

Al-Maliki, Muhammad Alwi. Syari'atullah al-Khalidah: Dirāsah fí Tärikh Tasyrì' Ahkām wa Maz|ahib al-Fuqahä, alA 'läm. Makkah: tnp, t.t.

Mazไkūr, Muhammad Salām. Al-Ijtihad fí Tasyrì' al-Islāmí. Kairo: Dār anNahḍah al-'Arabiyah, 1984.

Minhaji, Akh. "Ushul Fiqh dan Perubahan Sosial Dalam Persfektif Sejarah", dalam Amin Abdullah, dkk. Mencari Islam: Studi Islam Dengan Berbagai Pendekatan. Yogyakarta: Tiara Wacana, 2000.

Mubarok, Jaih. Metodologi Ijtihad Hukum Islam. Yogyakarta: UII Press, 2002.

Mu'ammar, M. Arfan. "Islam Progresif dan Ijtihad Progresif: Membaca Gagasan Abdullah Saeed", dalam M. Arfan Mu'ammar, dkk. Studi Islam Persfektif Insider/Outsider. Yogyakarta: IRCiSoD, 2013.

Mudzhar, M. Atho'. Membaca Gelombang Ijtihad: Antara Tradisi dan Liberasi. Yogyakarta: Titian Ilahi Press, 1998. 
Munawwir, Ahmad Warson. Kamus AalMunawwir. Surabaya: Pustaka Progressif, 1997.

Mustafá, Ibrahim. Al-Mu'jam al-Wasit. Ttp. : Mustafa al-Babi al-Halabi, t.t.

Nasution, Harun. Akal dan Wahyu dalam Islam. Jakarta: UI Press, 1986.

Nugroho, Anjar. "Fikih Kiri: Revitalisasi Ushul Fiqh untuk Revolusi Sosial", dalam jurnal $A l-J a^{-} m i$ 'ah, Vol. 43, No. 2, Tahun 2005.

Pujiono. Hukum Islam dan Dinamika Perkembangan Masyarakat: Menguak Pergeseran Prilaku Kaum Santri. Jember: STAIN Jember Press, 2011.

Al-Qardawi, Yusuf. Al-Qur'an Berbicara Tentang Akal dan Ilmu Pengetahuan, terj. Abdul Hayyie Al-Kattani, dkk. Jakarta: Gema Insani, 1998.

Roy, Muhammad. Ushul Figh Mazhab Aristoteles: Pelacakan Logika Aristoteles dalam Qiyas Ushul Figh. Yogyakarta: Safira Insani Press, 2004. - Dekonstruksi Teori Hukum Islam: Kritik Terhadap Konsep Mașlatiah Najmuddin al-Tüfi. Yogyakarta: Kaukaba, 2014.

Saeed, Abdullah. Islamic Thought an Introduction. New York: Rouledge, 2006.

Siregar, Amri. Ibn Hazm: Metode Zahiri Dalam Pembentukan Sumber Hukum Islam. Yogyakarta: Belukar, 2009.

Syahrur, Muhammad. Al-Kitab wa alQur'an: Qiräah al-Mu'așirah. Damascus: Dār al-Ahalli, 1991.

Syaltut, Mahmud. Isläm: 'Aqīdah wa Syarīah. Mesir: Dar al-Qalām, 1966.
Al-Syātibì, Abū Ishāq Ibrāhìm ibn Mūsā. al-Muwáfaqàt fî̀ Ușul al-Syaríah. Beirut: Dar al-Kutub al-'Ilmiyah, t.t.

Syukur, Amin "Keseimbangan Perkembangan Tasawuf dan Fiqh di Indonesia" dalam Noor Ahmad, dkk. Epistemologi Syara': Mencari Format Baru Fiqh Indonesia. Yogyakarta: Pustaka Pelajar, 2000.

Tim Penyususn. Kamus Besar Bahasa Indonesia. Jakarta: Pusat Bahasa Pendidikan Nasional, 2008.

Wijaya, Aksin. Teori Interpretasi Ibn Rusyd: Kritik IdeologisHermeneutis. Yogyakarta: LKiS, 2009.

- Nalar Kritis Epistemologi Islam: membincang Dialog Kritis Para Kritikus Muslim: AlGhazali, Ibnu Rusyd, Thaha Husein dan Abid Al-Jabiri. Yogyakarta: Nadi Pustaka, 2012.

Wirman, Hadi Putra. "Problematika Pendekatan Analogi (Qiyas) dalam Penetapan Hukum Islam: Telaah atas Pemikiran Ibn Hazm dan Ibn Qoyyim al-Jawziyah ", dalam Jurnal Asy-Syir'ah: Jurnal Syari'ah dan Hukum, Vol. 47, No. 1, Juni 2013.

Zayd, Nasr Hamid Abû. Naqd al-Khitab al-Dinin. Kairo: Sinā an-Nasyr, 1994.

Zubaedi, "Membangun Fiqh Yang Berorientasi Sosial: Dialektika Fiqh Dengan Realitas Empirik Masyarakat", Dalam Jurnal alJami'ah, Vol. 44, No. 2, Tahun 2006.

Al-Zuhayli, Wahbah. Ușul al-Fiqh alIslāmi. Beirut: Dār al-Fikr, 1998. 